Kumawula, Vol. 2, No.1, April 2019, Hal 23 - 40 DOI:http://10.24198/kumawula.v1i3. 23698

ISSN 2620-844X (online)

Tersedia online di http://jurnal.unpad.ac.id/kumawula/index

\title{
PERAN SISTEM MANAJEMEN PADA BUMDES DALAM PENINGKATAN PENDAPATAN ASLI DESA
}

\author{
Yayu Putri Senjani \\ UIN Sunan Kalijaga Yogyakarta \\ yayu.senjani@uin-suka.ac.id
}

\begin{abstract}
ABSTRAK
Penelitian ini bertujuan untuk menganalisis sistem manajemen Badan Usaha Milik Desa (BUMDes) dalam peningkatan Pendapatan Asli Desa (PADes). Sampel penelitian adalah pihak terkait dalam BUMdes Ngudi Mulyo dan warga Desa Kerten, Klaten, Jawa Tengah. Penelitian ini merupakan penelitan deskriptif kualitatif dan berbasis pengabdian kepada masyarakat. Hasil menunjukkan bahwa manajemen BUMDes masih sederhana namun telah memiliki rencana untuk perbaikan ke depan. Peran BUMDes untuk meningkatkan Pendapatan Asli Desa belum terlihat dikarenakan beberapa sistem manajemen yang belum memadai sehingga belum dapat diperhitungkan secara jelas besaran kontribusi BUMdes dalam PADes. Strategi yang ditawarkan peneliti adalah pengelolaan BUMDes dengan 5 sistem manajemen yang diperbaharui yaitu sistem manajemen keuangan, pemasaran, produksi, distribusi dan sumber daya manusia.
\end{abstract}

Kata Kunci: BUMDes, PADes, Manajemen Strategi

\section{THE ROLE OF MANAGEMENT SYSTEM IN BUMDES IN INCREASING THE REAL INCOME OF THE VILLAGE}

\begin{abstract}
This research aims to analyze the management system of Village Owned Enterprises (BUMDes) in relation to the increase of the Real Village Income (PADes). The research sample includes the relevant parties within BUMDes Ngudi Mulyo and the citizens of Kerten Village, Klaten, Central Java. This research uses a decriptive qualitative method based on civil service. The results indicate that the management of the BUMDes is still simple yet has many plans regarding improvements. The role of $B U M D e s$ in increasing the PADes has yet to be seen due to some management systems that are still below par. This results in the incapability to know how much BUMDes contributes to PADes. The strategy offered by the researcher is that BUMDes should be managed through 5 systems, which are, monetary management, marketing management, production management, distribution management, and human resources management.
\end{abstract}

Keywords: BUMDes, PADes, Strategy Management

\section{PENDAHULUAN}

Dalam Undang-undang nomor 6 tahun 2014 tentang Desa, pengertian Desa adalah kesatuan masyarakat hukum yang memiliki batas wilayah yang berwenang untuk mengatur dan 
mengurus urusan pemerintahan, kepentingan masyarakat setempat berdasarkan prakarsa masyarakat, hak asal usul, dan/atau hak tradisional yang diakui dan dihormati dalam sistem pemerintahan Negara Kesatuan Republik Indonesia.

Dalam undang-undang tersebut juga dinyatakan bahwa Kepala Desa sebagai pemerintah desa memiliki 15 kewenangan. Dari 15 kewenangan tersebut terdapat 5 kewenangan yang berkaitan dengan keuangan desa, yaitu untuk mengelola keuangan dan aset Desa, menetapkan anggaran pendapatan dan belanja desa, membina dan meningkatkan perekonomian desa serta mengintegrasikannya agar mencapai perekonomian skala produktif untuk sebesar-besarnya kemakmuran masyarakat desa, mengembangkan sumber pendapatan desa, dan mengusulkan serta menerima pelimpahan sebagian kekayaan negara guna meningkatkan kesejahteraan masyarakat desa.

Banyak upaya yang dapat dilakukan pemerintah desa untuk meningkatkan perekonomian desa untuk kemakmuran masyarakat desa. Salah satu upaya tersebut adalah dengan mendirikan Badan Usaha Milik Desa (BUMDes). Sejalan dengan tujuan pembentukan BUMDes yang tercantum dalam Peraturan Menteri Desa, Pembangunan Daerah Tertinggal, dan Transmigrasi nomor 4 tahun 2015 adalah untuk meningkatkan Pendapatan Asli Desa (PADes). BUMDes didirikan atas prakarsa pemerintah dan masyarakat desa yang didasarkan pada potensi khas desa. Potensi tersebut dapat dikembangkan dengan menggunakan sumber daya lokal baik alam maupun manusia. (Hidayat dan Fanida, Sehingga pendirian BUMDes bukan mandatori dari pemerintah pusat, melainkan lahir atas inisiatif pemerintah dan masyarakat desa untuk meningkatkan kesejahteraan mereka juga.

Namun dalam prakteknya, beberapa BUMDes hanya sepatas papan nama dan belum berjalan dengan baik agar dapat menyokong pendapatan desa (Ramadana dkk, 2016). Salah satu permasalahan yang menyebabkan BUMDes belum dapat meningkatkan ekonomi desa adalah penentuan bentuk badan hukum yang tepat (Dewi, 2014).

Di seluruh Indonesia, baru ada 2 yang berhasil dalam bidang Air Minum Kemasan. 2 BUMDEs tersebut berasal dari Provinsi Bali dan Jawa Barat. Desa Dawan Kaler, Dawan, Kulungkung Bali telah menghapus 70\% angka pengangguran di desanya dengan produksi air minum kemasan bermerk UDAKA. Sedangkan Garut, lebih baik lagi dengan inovasi air minum jenis Hexagonal pada Desa Sukarame. Dengan memahami potensi alam di desa tersebut, BUMDes Sukarame telah mensuplai air minum produksinya kepada kantor-kantor pemerintahan dan juga pasar umum. 
Air minum merupakan kebutuhan penting dalam kehidupan manusia. Jika Desa dapat memanfaatkan peluang dan kesempatan dari fenomena ini, maka BUMDes dapat berkembang dan bermanfaat bagi pertumbuhan ekonomi desa. Desa Kerten di Kecamatan Gantiwarno, Klaten, Jawa Tengah telah memiliki unit usaha air minum. Air minum tersebut diproduksi dengan mesin yang diperoleh atas bantuan dari Australia. Namun, ditengah persaingan usaha air minum lokal, maka pemerintah desa perlu melakukan inovasi produk untuk menggerakkan BUMDes.

Berdasarkan informasi di atas, penelitian ini dilakukan untuk mengidentifikasi dan menganalisis strategi peningkatan pendapatan asli desa melalui pengelolaan BUMDes. Melihat kondisi ekonomi yang stagnan di lingkungan masyarakat Desa Kerten, BUMDes diharapkan dapat membawa perubahan positif. Selain itu penelitian ini juga menganalisis persepsi masyarakat di sekitar BUMDes mengenai fungsi BUMDes dan kontribusi masyarakat terhadap manajemen BUMDes.

\section{TINJAKAN PUSTAKA}

\section{Keuangan Daerah/Desa}

Desa adalah kesatuan masyarakat hukum yang memiliki batas-batas wilayah yang berwenang untuk mengatur dan mengurus kepentingan masyarakat setempat, berdsarkan asal-usul dan adat istiadat setempat yang diakui dan dihormati dalam sistem Pemerintahan Negara Kesatuan Republik Indonesia. Keuangan desa merupakan semua hak dan kewajiban desa yang dapat dinilai dengan uang serta segala sesuatu berupa uang dan barang yang berhubungan dengan pelaksanaan hak dan kewajiban desa. Adapun hak dan kewajiban desa tersebut adalah menimbulkan pendapatan, belanja, pembiayaan dan pengelolaan keuangan desa.

Pada pasal 68 Undang-undang tentang Desa, sumber pendapatan desa terdiri atas Pendapatan Asli Desa, Bagi hasil pajak daerah Kabupaten Kota, bagian dari dana perimbangan keuangan pusat dan daerah, bantuan keuangan dari pemerintah di atasnya serta hibah dan sumbangan dari pihak ketiga yang tidak mengikat. Pada komponen sumber pendapatan di atas, yang berada di wilayah kewenangan pemerintah desa seutuhnya adalah Pendapatan Asli Desa (PADes). PADes dapat bersumber dari hasil usaha desa, hasil kekayaan desa, hasil swadaya dan partisipasi, hasil gotong royong dan lain-lain pendapatan asli desa yang sah. Hasil usaha desa merupakan jenis pendapatan asli desa yang diharapkan memiliki proporsi terbesar. 


\section{Badan Usaha Milik Desa (BUMDes)}

Menurut Permendes-PDTT nomor 4 tahun 2015, Badan Usaha Milik Desa merupakan badan usaha yang seluruh atau sebagian besar modalnya dimiliki oleh Desa melalui penyertaan secara langsung yang berasal dari kekayaan Desa yang dipisahkan guna mengelola aset, jasa pelayanan, dan usaha lainnya untuk sebesar-besarnya kesejahteraan masyarakat Desa. Dalam pasal 25 peraturan tersebut memuat strategi pengelolaan BUMDes yang bersifat bertahap dengan mempertimbangkan perkembangan dari inovasi yang dilakukan oleh BUMDes. Strategi tersebut dilakukan berdasarkan pilihan jenis usaha yang dipilih.

BUMDes dapat menjalan bisnis dengan berbagai klasifikasi jenis usaha diantaranya adalah:

a. Bisnis sosial sederhana yang memberikan pelayanan umum (serving) kepada masyarakat dengan memperoleh keuntungan finansial. Unit usaha yang dapat diterapkan oleh BUMDes meliputi air minum, usaha listrik, lumbung pangan dan sumber daya local dan teknologi tepat guna lainnya.

b. Bisnis penyewaan (renting) barang untuk melayani kebutuhan masyarakat Desa dan ditujukan untuk memperoleh Pendapatan Asli Desa.

c. Bisnis usaha perantara (brokering) yang memberikan jasa pelayanan keada warga seperti jasa pembayaran listrik.

d. Bisnis yang berproduksi dan/atau berdagang (trading) barang-barang tertentu untuk memenuhi kebutuhan masyarakat maupun dipasarkan pada skala pasar yang lebih luas.

e. Bisnis keuangan (financial business) yang memenuhi kebutuhan usaha-usaha skala mikro yang dijalankan oleh pelaku usaha ekonomi Desa.

f. Usaha bersama (holding) sebagai induk dari unit-unit usaha yang dikembangkan masyarakat Desa baik dalam skala lokal Desa maupun kawasan perdesaan.

Agar BUMDes dapat berkontribusi untuk meningkatkan PADes, maka perlu disusun sistem manajemen yang baik, khususnya sistem alokasi hasil usaha BUMDes. Hasil usaha BUMDes diperoleh dengan cara menghitung selisih antara pendapatan dan biaya yang dikeluarkan serta kewajiban dan penyusutan asset tetap setiap tahunnya. Sistem alokasi hasil usaha tersebut ditetapkan berdasarkan ketentuan yang diatur dalam Anggaran Dasar/Anggaran Rumah Tangga BUMDes. Perhitungan alokasi hasil suaha tersebut harus dikelola melalui sistem akuntansi yang sederhana. 
Pada tahun 2017 telah diumumkan BUMDes terbaik di Pulau Jawa berdasarkan jumlah omzet yang dihasilkan adalah:

Tabel 1

Data BUMDes Terbaik di Pulau Jawa Tahun 2017

\begin{tabular}{|l|l|l|l|l|}
\hline \multicolumn{1}{|c|}{$\begin{array}{c}\text { Nama } \\
\text { BUMDes }\end{array}$} & \multicolumn{1}{|c|}{ Usaha } & $\begin{array}{c}\text { Omset per } \\
\text { Tahun }\end{array}$ & \multicolumn{1}{|c|}{ Desa } & \multicolumn{1}{c|}{ Daerah } \\
\hline Tirtonirmoto & $\begin{array}{l}\text { Simpan } \\
\text { Pinjam }\end{array}$ & 8,7 milyar & Tirtonirmoto & $\begin{array}{l}\text { Bantul, } \\
\text { Yogyakarta }\end{array}$ \\
\hline Tirta Mandiri & $\begin{array}{l}\text { Kolam } \\
\text { Pemandian } \\
\text { dan Jasa } \\
\text { Wisata }\end{array}$ & 5 milyar & Ponggok & $\begin{array}{l}\text { Klaten, Jawa } \\
\text { Tengah }\end{array}$ \\
\hline $\begin{array}{l}\text { Karang } \\
\text { Kandri } \\
\text { Sejahtera }\end{array}$ & Suplier PLTU & 3 milyar & Karang Kandri & $\begin{array}{l}\text { Cilacap, } \\
\text { Jawa Tengah }\end{array}$ \\
\hline $\begin{array}{l}\text { Sejahtera } \\
\text { Jasa Wisata }\end{array}$ & 2 milyar & Blebaran & $\begin{array}{l}\text { Gunung } \\
\text { Kidul, } \\
\text { Yogyakarta }\end{array}$ \\
\hline Srisadani & $\begin{array}{l}\text { Pompanisasi, } \\
\text { Sewa Trop }\end{array}$ & 1,3 Miyar & Kedungprimen & $\begin{array}{l}\text { Bojonegoro, } \\
\text { Jawa Timr }\end{array}$ \\
\hline
\end{tabular}

Provinsi Jawa Tengah dan DI Yogykarta unggul dengan dua BUMDes. Namun jika dibandingkan dengan Yogyakarta, harusnya Jawa Tengah masih lebih unggul dikarenakan luas wilayah yang lebih banyak dibandingkan dengan Yogyakarta. Klaten adalah contoh kabupaten yang telah berhasil mengelola BUMDes. Berdasarkan data BUMDes yang diperoleh dari Kemendes bahwa Kecamatan Gantiwarno baru ada 1 BUMDes yaitu di Desa Towangsan. Dengan adanya BUMDes terbaik di Klaten, maka diharapkan dapat membantu desa-desa lainnya untuk dapat mengembangkan potensi desanya melalui pengelolaan BUMDes yang professional.

3. Manajemen Bisnis

Bisnis adalah kegiatan menjual barang atau jasa yang dapat memberikan keuntungan. Manajemen bisnis dapat diartikan sebagai kegiatan perencanaan, pengelolaan dan operasional sebuah usaha. Setidaknya terdapat 5 komponen dalam manejemen bisnis yaitu:

a. Manajemen Keuangan

Manajemen keuangan dimulai dari penganggaran sampai pelaporan.

b. Manajemen Pemasaran

Tujuan dari manejemn pemasaran ini adalah untuk meningkatkan penjualan di pasar.

c. Manajemen Produksi

Produksi inti dari jalannya bisnis. Produksi dimulai sejak bahan baku sampai barang jadi. 


\section{d. Manajemen Distribusi}

Distribusi sangat penting untuk kelancaran proses pemasaran.

e. Manajemen Sumber Daya Manusia

Tidak ada system yang berhasil tanpa adanya sumber daya manusia yang berkualitas.

\section{Teori Tingkat Aspirasi (Level of Aspiration Theory)}

Teori tingkat Aspirasi memiliki 2 asumsi. Asumsi yang pertama adalah bahwa seseorang dimotivasi oleh keinginan untuk merasakan sukses dan menghindari merasakan gagal. Asumsi kedua adalah bahwa persepsi terhadap keberhasilan dan kegagalan subjektif daripada tingkat objektif (Weinder, 1989 dalam Birnberg et all, 2006). Teori ini digunakan untuk menganalisis persepsi masyarakat tentang keinginan untuk berkontribusi dalam BUMDes.

\section{DESAIN PENELITIAN}

Jenis penelitian ini adalah penelitian deskriptif yang didasarkan pertanyaan bagaimana sistem manajemen BUMDes agar dapat memberikan pengaruh pada peningkatan pendapatan Desa. Penelitian ini merupakan penelitian berbasis pengabdian.

Penelitian ini juga disebut sebagai jenis penelitian kualitatif. Penelitian kualitatif adalah penelitian yang menggunakan latar alamiah, dengan maksud menafsirkan fenomena yang terjadi dan dilakukan dengan jalan melibatkan berbagai metode yang ada (Denzin dan Lincoln, 1987 dalam Moloeng, 2014). Berikut adalah fungsi dan pemanfaatan penelitian kualitatif dalam penelitian ini:

1. Untuk keperluan evaluasi

2. Bermaksud melakukan penelitian yang mendalam

3. Upaya pemahaman penelitian perilaku dan penelitian motivasional

Alat analisis kualitatif digunakan untuk mengevaluasi sistem manajemen BUMDes saat ini dan upaya merancang sistem manajemen yang diperbaharui. Selain itu, peneliti juga menggunakan alat analisis kuantitatif deskriptif dengan memilih responden berdasarkan metode purposive sampling. Syarat dan kriteria yang ditetapkan untuk menetapkan responden adalah:

1. Merupakan warga Desa Kerten

2. Mengikuti kegiatan penyuluhan yang dilaksanakan saat periode penelitian.

3. Mengetahui tentang BUMDES di Desa Kerten 
Sumber dan jenis data pada penelitian ini adalah kata-kata, tindakan dan dokumen yang terkait dengan untuk menjawab pertanyaan penelitian. Penelitian akan dilakukan dengan metode wawancara dan observasi. Analisis terhadap data dan informasi terkait juga dilakukan untuk mencapai hasilnya. Data yang digunakan dalam penelitian ini meliputi data primer dan sekunder. Data yang terkumpul akan dianalisis dengan menggunakan teknik analisis data kualitatif model interaktif dari Miles dan Huberman dalam Wijayanti dkk (2012).

Metode pengumpulan data adalah dengan metode wawancara. Wawancara dilakukan dengan menggunakan jenis wawancara baku terbuka yang berisi tentang pertanyaan apa saja yang harus diberikan kepada informan. Bentuk pertanyaan yang disampaikan adalah yang berkaitan dengan pendapat seseorang (dalam hal ini adalah tentang BUMDes dan unit usahanya).

\section{HASIL DAN DISKUSI}

1. Profil Objek Penelitian

a. BUMDES Ngudi Mulyo, Kerten

BUMDES Ngudi Mulyo didirikan berdasarkan Peraturan Desa Kerten nomor 1 tahun 2017 tanggal 4 Januari 2017. Lokasi BUMDES ini ada di Desa Kerten, Kecamatan Gantiwarno, Kabupaten Klaten, Jawa Tengah. Selain sebagai upaya menampung seluruh kegiatan di bidang ekonomi dan/atau pelayanan umum yang dikelola oleh Desa dan/atau kerjasama antar Desa, BUMDES Ngudi Mulyo juga bertujuan meningkatkan pendapatan masyarakat desa dan pendapatan asi desa.

Sejak berdirinya, BUMDES Ngudi Mulyo dipimpin oleh seorang ketua yang bernama Harsa Akirul Bowo. Dalam menjalankan pengelolaan BUMDES, Bapak Harsa Akirul Bowo dibantu oleh Ibu Kusmiyati sebagai Sekretaris dan Bapak Suparno sebagai Bendahara. Mereka diangkat menjadi pengelola BUMDES periode 2017-2022 berdasarkan Surat Keputusan Kepala Desa Kerten nomor 3 tahun 2017.

Saat ini, BUMDES Ngudi Mulyo telah menyusun Anggaran Dasar yang telah disahkan pada tanggal 30 Januari 2017 oleh Bapak Sarta, Amd selaku Kepala Desa Kerten. Dari 12 Bab dalam Anggaran Dasar yang merupakan panduan bagi pengurus dalam menjalankan BUMDES, belum seluruhnya diimplementasikan. Hasil secara detail akan disampaikan pada subbab berikutnya dalam laporan penelitian ini. Sampai laporan penelitian ini disusun, BUMDES Ngudi Mulyo belum menyusun Anggaran Rumah Tangga. 
b. Responden Penelitian

Responden pada penelitian ini dibagi menjadi 2 (dua), yang pertama adalah responden untuk mengukur tingkat pengetahuan dan persepsi warga mengenai BUMDES, sedangkan kelompok kedua adalah responden yang digunakan untuk menilai partisipasi warga dalam manajemen BUMDES.

Responden kelompok pertama terdiri dari 59 responden yang tersebar ke dalam 6 Dusun. Berikut adalah data responden berdasarkan jenis kelamin:

Gambar 1

Data Responden Tahap 1 Berdasarkan Jenis Kelamin

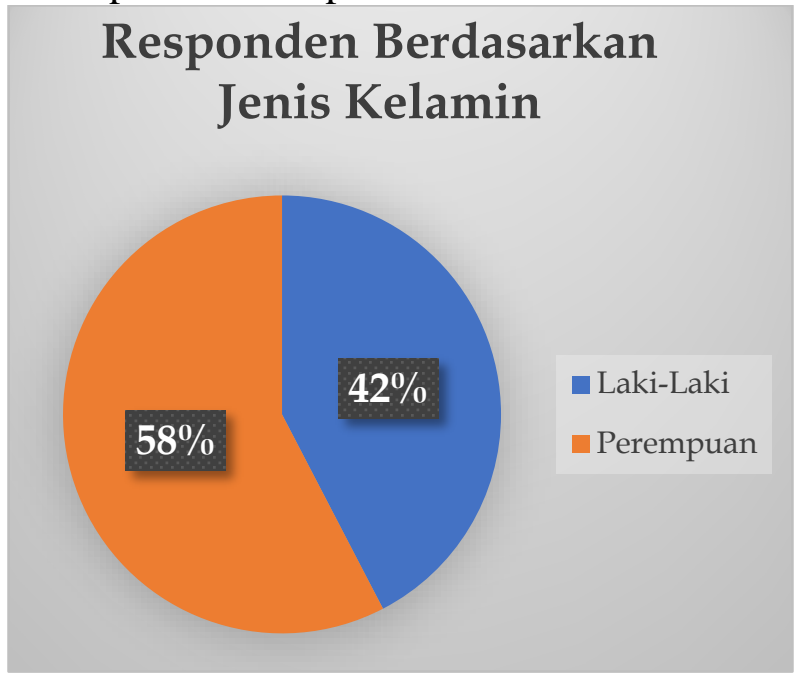

Berikut adalah data responden berdasarkan Usia yang didominasi oleh usia produktif yaitu antara 31-50:

Gambar 2

Data Responden Tahap 1 Berdasarkan Usia

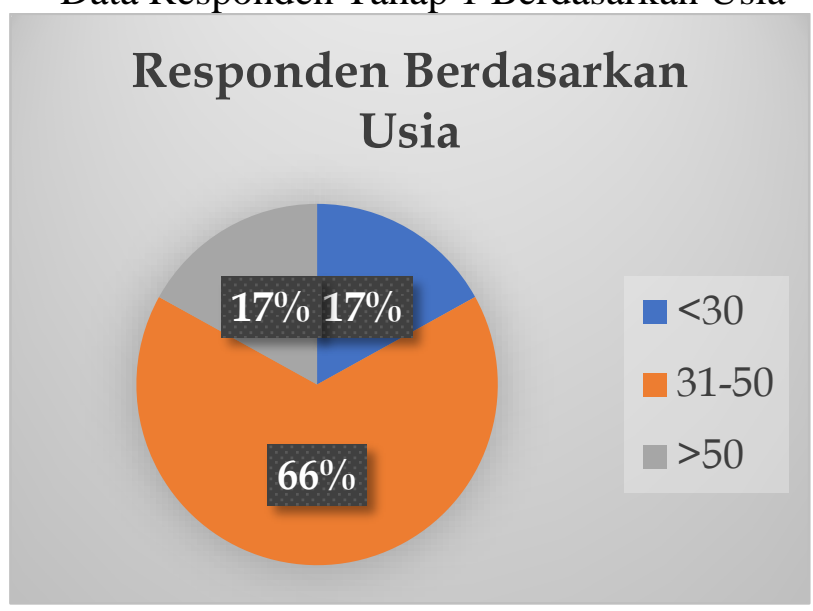

Jika dilihat berdasarkan Pendidikan terakhir, responden terbanyak adalah yang berpendidikan terakhir SMA/SMK. Data tersebut dapat di gambarkan pada diagram berikut ini: 
Gambar 3

Data Responden Tahap 1 Berdasarkan Pendidikan Terakhir

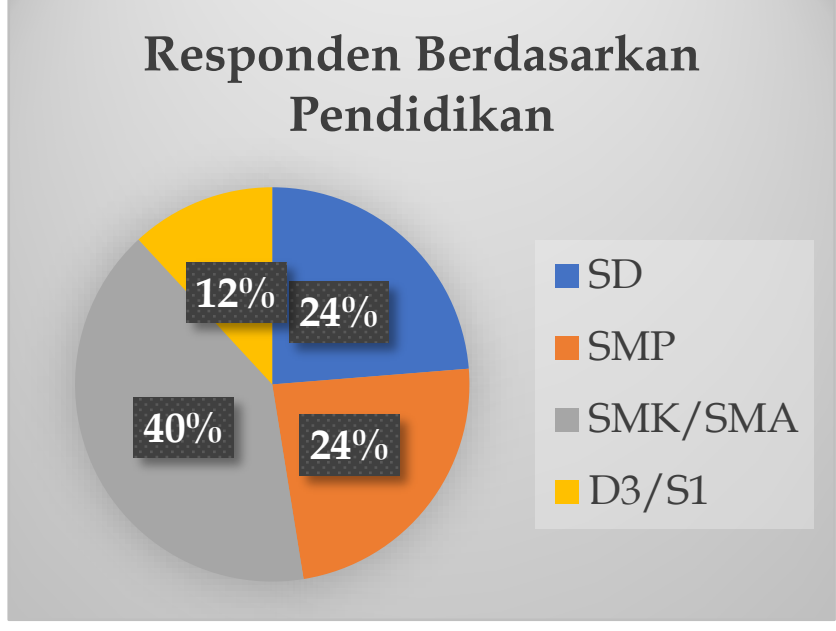

Sedangkan untuk responden kelompok kedua dapat dilihat pada tabel di bawah ini:

Tabel 2

Data Responden Tahap 2

\begin{tabular}{|c|l|c|}
\hline No. & \multicolumn{1}{|c|}{ Jenis Responden } & Jumlah \\
\hline 1 & Warga & 2 \\
\hline 2 & Perangkat RT/RW & 6 \\
\hline 3 & Perangkat Desa & 1 \\
\hline 4 & Pengelola BUMDES & 2 \\
\hline 5 & BPD & 1 \\
\hline \multicolumn{2}{|l}{} \\
\hline
\end{tabular}

2. Hasil Olah Data Kuesioner Penelitian

a. Tingkat pengetahuan dan persepsi warga mengenai BUMDES di Desa Kerten

Untuk menjawab pertanyaan pertama dalam penelitian ini, peneliti menyebarkan kuesioner kepada warga. Dari 60 kuesioner yang disebar, terdapat 59 kuesioner yang terjawab dengan lengkap.

Hasil penglolahan data yang diperoleh dari jawaban responden menunjukkan bahwa warga yang menjadi responden telah mengetahui peran BUMDES di Desa Kerten. Total skor keseluruhan mencapai angka 2,79 (dari skala 4). Dari 10 pertanyaan yang diajukan skor tertinggi mengenai persepsi warga tentang peran BUMDES adalah pada pertanyaan ke 8 yaitu Keuangan unit usaha Desa harus dilaporkan kepada masyarakat. Dari hasil tersebut dapat ditarik kesimpulan bahwa warga sangat megingingkan transparansi keuangan BUMDES kepada warganya. 
Sementara itu, hasil yang terendah adalah pada pernyataan ke-7 (unit usaha desa meningkatkan pendapatan saya). Skor pernyataan tersebut hanya mencapai angka 2,32 yang berarti warga cenderung tidak setuju terhadap pernyataan tersebut. Warga belum merasakan keberadaan BUMDES dapat meningkatkan pendapatan mereka. Hal ini dikarenakan mayoritas warga tidak menjadi pegawai pengelola BUMDES sehingga tidak merasakan dampak langsung terhadap peran BUMDES bagi peningkatan pendapatan warga.

Skor persepsi warga mengenai BUMDES Ngudi Mulyo di Desa Kerten dapat dilihat pada tabel di bawah ini:

Tabel 3

Hasil Survey tahap 1

\begin{tabular}{|l|l|l|l|}
\hline No. & \multicolumn{1}{|c|}{ Pernyataan } & Skor & Keterangan \\
\hline 1 & $\begin{array}{l}\text { Saya mengetahui bahwa desa saya memiliki } \\
\text { unit usaha }\end{array}$ & 2,95 & $\begin{array}{l}\text { Cenderung } \\
\text { Setuju }\end{array}$ \\
\hline 2 & $\begin{array}{l}\text { Produk yang dijual oleh unit usaha desa } \\
\text { sesuai dengan kebutuhan penduduk }\end{array}$ & 2,71 & $\begin{array}{l}\text { Cenderung } \\
\text { Setuju }\end{array}$ \\
\hline 3 & $\begin{array}{l}\text { Unit usaha membuka lapangan kerja bagi } \\
\text { penduduk desa }\end{array}$ & 2,81 & $\begin{array}{l}\text { Cenderung } \\
\text { Setuju }\end{array}$ \\
\hline 4 & $\begin{array}{l}\text { Unit usaha desa memanfaatkan sumber daya } \\
\text { alam di desa }\end{array}$ & 2,86 & $\begin{array}{l}\text { Cenderung } \\
\text { Setuju }\end{array}$ \\
\hline 5 & $\begin{array}{l}\text { Sejak adanya unit usaha saya merasa desa } \\
\text { saya semakin maju }\end{array}$ & 2,72 & $\begin{array}{l}\text { Cenderung } \\
\text { Setuju }\end{array}$ \\
\hline 6 & $\begin{array}{l}\text { Sejak adanya unit usaha saya merasa } \\
\text { pendapatan desa saya meningkat }\end{array}$ & 2,70 & $\begin{array}{l}\text { Cenderung } \\
\text { Setuju }\end{array}$ \\
\hline 7 & $\begin{array}{l}\text { Unit usaha desa meningkatkan pendapatan } \\
\text { saya }\end{array}$ & 2,32 & $\begin{array}{l}\text { Cenderung } \\
\text { Tidak Setuju }\end{array}$ \\
\hline 8 & $\begin{array}{l}\text { Keuangan unit usaha desa harus dilaporkan } \\
\text { kepada masyarakat }\end{array}$ & 3,22 & $\begin{array}{l}\text { Cenderung } \\
\text { Setuju }\end{array}$ \\
\hline 9 & $\begin{array}{l}\text { Unit usaha desa saya sudah dikelola dengan } \\
\text { baik }\end{array}$ & 2,75 & $\begin{array}{l}\text { Cenderung } \\
\text { Setuju }\end{array}$ \\
\hline 10 & $\begin{array}{l}\text { Pengelola unit usaha desa adalah orang yang } \\
\text { professional }\end{array}$ & 2,81 & $\begin{array}{l}\text { Cenderung } \\
\text { Setuju }\end{array}$ \\
\hline Rata-rata & $\begin{array}{l}\text { Cenderung } \\
\text { Setuju }\end{array}$ \\
\hline
\end{tabular}

Keterangan:

0,5-1,5 : Cenderung Sangat Tidak Setuju

1,5-2,5 : Cenderung Tidak Setuju

2,5-3,5 : Cenderung Setuju

3,5-4,0 : Cenderung Sangat Setuju 
b. Tingkat partisipasi warga dalam manajemen BUMDES di Desa Kerten

Untuk menjawab pertanyaan penelitian kedua ini, kami mengajukan pertanyaan kepada warga sebagai berikut:

"Apakah Anda akan bekontribusi langsung kepada unit usaha desa? Jika ya, Jelaskan bentuk kontribusi Anda? Jika tidak, berikan alas an Anda?”

Dari 59 responden, 28 orang (47,46\%) menjawab ya (bersedia berpartisipasi dalam manajemen BUMDes), dan yang menjawab tidak berjumlah sedikit lebih banyak dibanding yang menjawab ya, yaitu 31 orang (52,54\%). Hal ini menunjukkan masih banyak warga yang belum berperan/ingin berperan dalam manajemen BUMDes di Desa Kerten.

Responden yang bersedia berkontribusi/berpartisipasi memilih menjadi pembeli produk yang dijual oleh BUMDes berjumlah 15 orang atau mayoritas dari responden yang menajawab ya. Sedangkan 9 responden memilih menjadi pegawai/pengelola, 1 orang bersedia menjadi pemodal dan yang lainnya sekedar memberikan ide pengembangan.

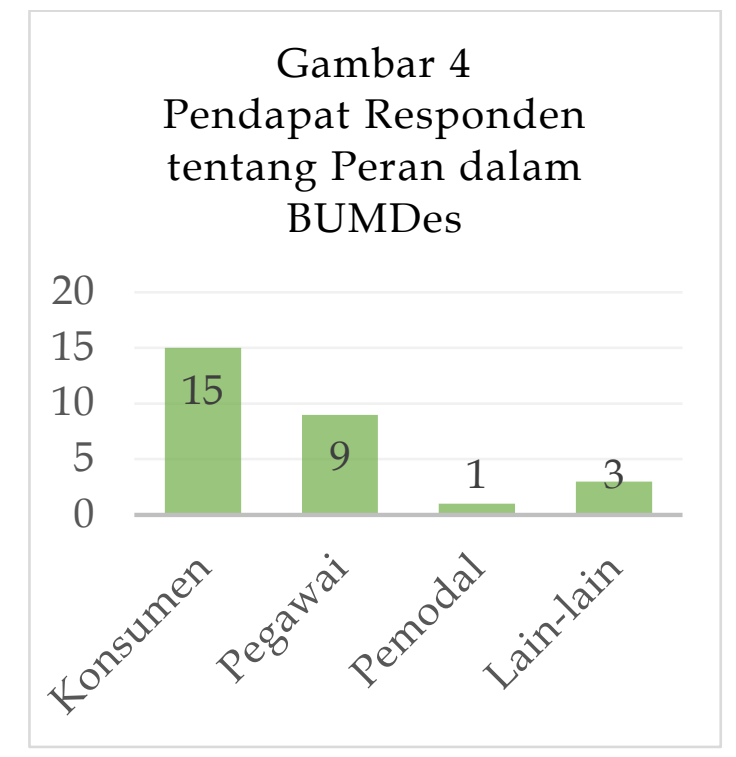

Di sisi lain, 31 responden yang menjawab tidak berkontribusi memiliki beberapa alasan yang dapat dilihat pada bagan di bawah ini: 


\section{Gambar 5}

Pendapat Responden tentang Tidak Akan Berperan dalam BUMDes

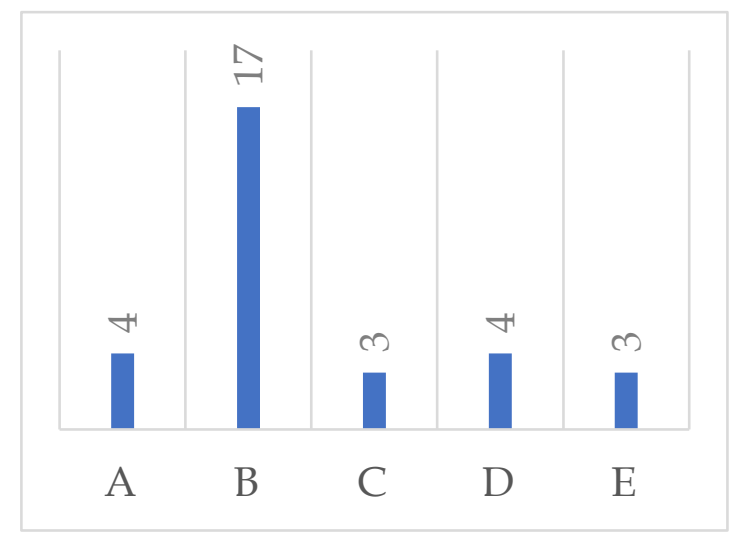

Keterangan:

A. Responden merupakan bukan usia produktif

B. Responden Sudah memiliki kesibukan/ pekerjaan lain

C. Responden merasa tidak memahami BUMDes dan unit usahanya

D. Responden memilih membiarkan orang lain yang mengelola BUMDes

E. Pendapat lainnya (mengelola usaha sendiri dan tidak setuju adanya unit usaha dalam BUMDes)

Berdasarkan hasil analisis tersebut, maka dapat dinyatakan bahwa peran masyarakat terhadap manajemen BUMDes Ngudi Mulyo, Desa Kerten belum optimal. Hal ini ditunjukan dari jumlah responden yang menyatakan tidak akan berkontribusi masih lebih banyak disbanding yang bersedia (31:28 atau 52,54\% : 47,46\%). Bahkan, kami menemukan masih terdapat responden yang mewakili masyarakat Desa Kerten belum memahami bahwa Desa mereka telah memiliki Unit Usaha yang dikelola oleh BUMDes.

BUMDes Ngudi Mulyo, Desa Kerten yang baru memiliki 2 produk unggulan yaitu Air Minum Quaten dan Madu Lanceng masih belum menjadi pilihan utama bagi masyarakat. hal ini dibuktikan dengan jumlah mayoritas responden yang tidak bersedia berpartisipasi dalam manajemen BUMDes disebabkan oleh mereka telah memiliki pekerjaan/kesibukkan lain yang masih dianggap lebih baik dan menarik dibanding bergabung untuk mengelola BUMDes. 
c. Tingkat peran BUMDES dalam Peningkatan Pendapatan Asli Desa Kerten.

Pada saat penelitian ini dilakukan, informasi mengenai Pendapatan Asli Desa belum dapat diperoleh. Informasi mengenai keuangan masih merupakan hal yang tabu dan tidak biasa untuk dibuka ke hadapan publik. Dalam kuesioner yang telah disusun dan disampaikan kepada pihak Desa, tidak ada yang memberikan jawaban dan disertai data valid mengenai pertanyaan tersebut. Hal ini menunjukkan bahwa belum terdapat peran BUMDes dalam peningkatan Pendapatan Asli Desa Kerten.

Penyebab belum adanya peran langsung dan nyata dari BUMDes terhadap Peningkatan PAD, adalah:

1) BUMDes baru saja didirikan tahun 2017 dan baru mulai dikelola dengan serius di tahun 2018.

2) BUMDes hanya memiliki 2 unit usaha. Air minum Quaten dengan jumlah gallon yang masih terbatas sehingga belum memperoleh pendapatan yang tinggi dan produk madu lanceng yang masih tahap produksi sehingga belum menyumbang penghasilan bagi BUMDes.

3) Unit usaha Quaten telah ada sebelum BUMDes resmi berdiri. Tahun 2018 adalah tahun pengalihan manajemen yang dihadapkan pada kondisi keuangan belum dapat diketahui secara pasti jumlahnya.

4) Belum terdapat sistem bagi hasil yang jelas antara karena sistem permodalan juga belum ditetapkan dengan resmi.

Namun demikian, pengelola BUMDes, perangkat desa dan warga berkomitmen untuk menjalankan BUMDes dengan sebaik mungkin agar tujuan didirikannya BUMDes dapat tercapai.

Berikut ini akan dipaparkan diskusi pembahasan atas temuan yang dihasilkan saat penelitian. Selain menjawab 3 pertanyaan penelitian di atas, penelitian ini memaparkan temuan mengenai beberapa komponen yang telah ditanyakan kepada beberapa warga, pihak desa dan pengelola BUMDes. Berikut adalah paparan tentang kondisi existing, harapan dan temuan yang merupakan hal-hal yang sudah dan belum sesuai dengan teori atau peraturan perundangan-undangan yang berlaku. 
Tabel 4

Analisis Sistem Manajemen BUMDes Existing dan Perbaikan yang ditawarkan.

\begin{tabular}{|c|c|c|}
\hline No. & Temuan & Perbaikan \\
\hline A. & Jenis Usaha & \\
\hline 1 & $\begin{array}{l}\text { Jenis usaha telah sesuai dengan } \\
\text { peraturan yaitu masuk dalam } \\
\text { kategori pelayanan umum }\end{array}$ & Sudah tepat \\
\hline 2 & $\begin{array}{l}\text { BUMDes belum banyak menggali } \\
\text { potensi bisnis lain dikarenakan } \\
\text { fokus pada pengelolaan usaha } \\
\text { yang ada terlebih dahulu }\end{array}$ & $\begin{array}{l}\text { Perlu identifikasi dan } \\
\text { analisis pasar mengenai } \\
\text { kebutuhan warga }\end{array}$ \\
\hline B. & Manajemen Keuangan & \\
\hline 1 & $\begin{array}{l}\text { Memiliki SDM yang berlatar } \\
\text { belakang Pendidikan Akuntansi } \\
\text { untuk melaksanakan manajemen } \\
\text { keuangan BUMDes dan unit usaha } \\
\text { di bawahnya }\end{array}$ & Telah baik \\
\hline 2 & $\begin{array}{l}\text { Telah memiliki proses } \\
\text { penganggaran yang memadai }\end{array}$ & Telah baik \\
\hline 3 & $\begin{array}{l}\text { Belum menerapkan } \\
\text { akuntansi BUMDes }\end{array}$ & $\begin{array}{l}\text { Perlu menggunakan sistem } \\
\text { akuntansi UMKM }\end{array}$ \\
\hline 4 & $\begin{array}{l}\text { Belum memiliki sistem } \\
\text { permodalan dan bagi hasil yang } \\
\text { memadai dan adil }\end{array}$ & $\begin{array}{l}\text { Perlu dibuat sistem } \\
\text { permodalan sederhana dari } \\
\text { masyarakat setempat }\end{array}$ \\
\hline C. & Manajemen Pemasaran & \\
\hline 1 & $\begin{array}{l}\text { Product : Varian kemasan terbatas } \\
\text { dan belum cukup menarik }\end{array}$ & Perlu inovasi \\
\hline 2 & Price : Telah sesuai dan wajar & Telah baik \\
\hline 3 & $\begin{array}{l}\text { Promotion : Masih belum } \\
\text { melibatkan warga sebagai agen } \\
\text { pemasaran Produk BUMdes }\end{array}$ & $\begin{array}{l}\text { Perlu melibatkan warga } \\
\text { untuk pemasaran optimal }\end{array}$ \\
\hline 4 & $\begin{array}{l}\text { Place : Terbatas pada desa Kerten } \\
\text { dikarenakan desa Tetangga juga } \\
\text { memiliki produk yang sejenis }\end{array}$ & $\begin{array}{lr}\text { Dapat dioptimalkan } \\
\text { dengan mengajukan izin } \\
\text { edar produk yang lebih luas }\end{array}$ \\
\hline D. & Manajemen Produksi & \\
\hline 1 & $\begin{array}{l}\text { Kualitas air minum Quaten belum } \\
\text { teruji secara resmi di laboratorium } \\
\text { BPOM, namun telah diuji di } \\
\text { Laboratorium Puskesmas dengan } \\
\text { hasil Aman untuk Diminum }\end{array}$ & \begin{tabular}{l}
\multicolumn{3}{l}{ Dapat dilakukan pengujian } \\
lebih lanjut di \\
Laboratorium
\end{tabular} \\
\hline 2 & $\begin{array}{lrr}\text { Masih } & \text { ditemukan } & \text { stock air } \\
\text { kemasan } & \text { gallon di Gudang depot } \\
\text { dan } & \text { belum } & \text { langsung } \\
\text { didistribusikan kepada konsumen }\end{array}$ & $\begin{array}{l}\text { Dapat dibuat sistem jadwal } \\
\text { pengisian agar tidak terlalu } \\
\text { banyak stock yang } \\
\text { mengendap }\end{array}$ \\
\hline
\end{tabular}




\begin{tabular}{|c|c|c|}
\hline E. & Manajemen Distribusi & \\
\hline 1 & $\begin{array}{l}\text { Saat ini distribusi masih aman dan } \\
\text { tercukupi dengan menggunakan } \\
\text { kendaraan pengangkut roda 3, } \\
\text { namun dengan perencanaan akan } \\
\text { menambah unit gallon, maka } \\
\text { pengelola telah menganggarkan } \\
\text { menambah kendaraan distribusi di } \\
\text { tahun depan }\end{array}$ & $\begin{array}{l}\text { Telah baik karena telah } \\
\text { memiliki perencanaan } \\
\text { penambahan alat distribusi }\end{array}$ \\
\hline 2 & $\begin{array}{l}\text { Distribusi yang dilakukan melalui } \\
\text { sistem penitipan di beberapa toko } \\
\text { kelontong belum sesuai dengan } \\
\text { Keputusan Menteri Perindustrian } \\
\text { dan Perdagangan RI No. } \\
\text { 651/MPP/kep/10 2004 tentang } \\
\text { Persyaratan Teknis Depot Air } \\
\text { Minum dan Perdagangannya. }\end{array}$ & $\begin{array}{l}\text { Perlu menyesuaikan } \\
\text { dengan aturan terkait }\end{array}$ \\
\hline F. & $\begin{array}{l}\text { Manajemen Sumber } \\
\text { Manusia }\end{array}$ & \\
\hline 1 & $\begin{array}{l}\text { Struktur kepengurusan sudah } \\
\text { memadai untuk saat ini, namun } \\
\text { pengelola telah memiliki } \\
\text { perencanaan pengembangan unit } \\
\text { usaha sehingga akan menambah } \\
\text { pegawai di tahun depan }\end{array}$ & $\begin{array}{l}\text { Dapat ditambahkan seiring } \\
\text { dengan pengembangan } \\
\text { BUMDes ke depan }\end{array}$ \\
\hline 2 & $\begin{array}{l}\text { Belum terdapat sistem pengupahan } \\
\text { yang menarik bagi warga agar } \\
\text { berminat untuk berkontribusi } \\
\text { sebagai pegawai di BUMDes }\end{array}$ & $\begin{array}{l}\text { Dapat ditingkatkan ketika } \\
\text { produk semakin banyak } \\
\text { dan manajemen keuangan } \\
\text { telah stabil }\end{array}$ \\
\hline 3 & $\begin{array}{l}\text { Belum ada sistem pelatihan untuk } \\
\text { mengembangkan kemampuan } \\
\text { pegawai dikarenakan proses bisnis } \\
\text { unit usaha saat ini tidak } \\
\text { memerlukan keahlian khusus. }\end{array}$ & $\begin{array}{l}\text { Dapat bekerjasama dengan } \\
\text { perguruan tinggi untuk } \\
\text { mendapatkan pelatihan } \\
\text { agar kemampuan pegawai } \\
\text { semakin berkembang }\end{array}$ \\
\hline
\end{tabular}

\section{KESIMPULAN}

BUMDes memiliki peran penting bagi upaya peningkatan pendapatan desa. BUMDes diharapkan dapat membawa pengaruh positif bagi masyarakat desa. Selain itu, tujuan lain didirikan BUMDes adalah untuk menciptakan lapangan kerja sehingga dapat mengurangi pengangguran, memanfaatkan potensi khas desa yang berupa kekayaan hasil alam maupun hasil kreatifitas warganya. BUMDes Ngudi Mulyo yang berlokasi di Desa Kerten, Kecamatan Gantiwarno, Kabupaten Klaten, Jawa Tengah didirikan dari keingingan penduduk Desa. Berawal di tahun 2017 dan baru mulai aktif di tahun 2018 
dengan dua unit usaha yang telah berjalan yaitu Air Minum RO Quaten dan Madu Lanceng.

Dengan Sumber daya yang terbatas, 3 orang pengelola, 2 karyawan produksi Quaten dan 1 karyawan distribusi, BUMDes Ngudi Mulyo telah menjalankan proses bisnisnya dengan pengelolaan yang sederhana namun masih cukup memadai untuk saat ini. Pengelolaan atau manajemen yang telah dilakukan BUMdes tersebut meliputi sistem keuangan dengan catatan sederhana kas masuk dan keluar dan belum menerima penyertaan modal dari luar, sistem promosi metode langsung (dari mulut ke mulut), sistem produksi dengan siklus yang singkat, sistem distribusi yang masih terbatas jumlah kendaraan dan sistem pengelolaan SDM yang seperti pegawai harian lepas.

Untuk meningkatkan pendapatan BUMDes, yang secara langsung akan akan meningkatkan Pendapatan Asli Desa, maka diperlukan strategi manajemen BUMDes yang lebih baik. Sistem Manajemen BUMDes perlu diperbaharui terdiri dari Manajemen Keuangan, Manajemen Pemasaran, Manajemen Produksi, Manajemen Distribusi, dan Manajemen Sumber Daya Manusia. Strategi tersebut diperoleh berdasarkan hasil survey yang dilakukan di Desa Kerten selama periode penelitian dan informasi yang diperoleh dari BUMDes Ponggok yang merupakan salah satu BUMDes terbaik di Indonesia khususnya di Jawa.

Keterbatasan dalam penelitian ini adalah, peneliti belum mendapatkan akses langsung terhadap catatan dan laporan keuangan pemerintah Desa, sehingga belum dapat diperoleh analisis mengenai hubungan BUMDes dengan Pendapatan Asli Desa. Selain itu, pada saat periode penelitian, unit usaha Quaten masih dalam masa transisi pengalihan manajemen ke pengelola BUMDes sehingga data-data keuangan belum dapat ditelusuri lebih dalam. untuk produk Madu Lanceng juga baru dimulai produksi dan belum dipanen sehingga peneliti belum dapat menganalisis lebih detail mengenai manajemen produksi, distribusi dan pemasaran.

Saran yang dapat penulis ajukan untuk penelitian berikutnya adalah menentukan waktu yang tepat untuk pengambilan data agar dapat menganalisis dengan lebih komprehensif dan lebih detail. Selain itu, perlu adanya komunikasi lebih awal kepada pemerintah desa agar dapat memberikan izin terhadap akses informasi mengenai data keuangan di tingkat desa. Pemahaman mengenai kebutuhan data adalah hanya untuk penelitian ilmiah, juga perlu disampaikan kepada pihak terkait. 
Bagi pemerintah desa diharapkan dapat lebih memberikan perhatian terhadap BUMDes. Cara-cara yang bisa dilakukan diantaranya adalah memberikan slot anggaran operasional BUMDes dalam anggaran Pemerintah Desa dan himbauan kepada warga untuk bekerja sama memajukan BUMDes baik dengan cara membeli produk BUMDes maupun menjadi pegawai BUMDes.

Kepada pengelola BUMDes dan Unit Usaha untuk dapat menigkatkan kuantitas dan kualitas koordinasi. Evaluasi secara berkala dan melakukan perbaikan juga penting dilakukan bersama agar BUMDes dapat berjalan dengan baik dan berkembang.

\section{DAFTAR REFERENSI}

Anwar, Cahirul dkk. Analisis Penggunaan Anggaran Biaya Administrasi Umum Dan Efisiensi Terhadap Peningkatan Kinerja Supervisor. JURNAL Akuntansi \& Keuangan Vol. 3, No. 1, Maret 2012. Halaman 139 - 152.

Birnberg J., Luft J, dan Shields M.D., 2006. Phsyhology Theory in Management Accounting Research. Handbook of Mangement Accounting Research. Elsevier.

Copra S. dan Meindl, P. (2010). Supply Chain Management: Strategy, Planning and Operation. $4^{\text {th }}$ ed. NJ: Pearson Education.

Dewi, Amelia Sri Kusuma. 2014. Peranan Badan Usaha Milik Desa (Bumdes) sebagai Upaya dalam Meningkatkan Pendapatan Asli Desa (Pades) serta Menumbuhkan Perekonomian Desa. Journal of Rural and Development. Volume V No. 1 Februari 2014

Dewi, Amelia Sri Kusuma. 2014. Peranan Badan Usaha Milik Desa (BUMDEs) Sebagai Upaya Dalam Meningkatkan Pendapatan Asli Desa (PADes) Serta Menumbuhkan Perekonomian Desa. Journal of Rural and Development. Vol. 5 No. 1.

Harmono. 2009. Manajemen Keuangan berbasis Balance Scorecard Pendekatan Teori, Kasus dan Riset Bisnis. Jakarta : PT Bumi Aksara

Hidayat, Akhmad Bagus dan Eva Hany Fanida. 2016. Strategi Pengelolaan Badan Usaha Milik Desa (BUMDEs) dalam Upaya Pengembangan BUMDesa Surya Sejahtera Desa Kedungturi Kecamatan Taman Kabupaten Sidoarjo. Publika Jurnal Ilmu Administrasi Negara. Vol. 4 nomor 9. 
Keputusan Kepala Desa Kerten Nomor 03 Tahun 2017 Tentang Penetapan Kepengurusan Bumdesa Ngudi Mulyo Desa Kerten, Kecamatan Gantiwarno

Keputusan Menteri Perindustrian dan Perdagangan Republik Indonesia Nomor 651/Mpp/ Kep/10/2004 Tentang Persyaratan Teknis Depot Air Minum Dan Perdagangannya Menteri Perindustrian Dan Perdagangan Republik Indonesia

Peraturan Menteri Desa, Pembangunan Daerah Tertinggal, Dan Transmigrasi Republik Indonesia Nomor 4 Tahun 2015 tentang Pendirian, Pengurusan Dan Pengelolaan, dan Pembubaran Badan Usaha Milik Desa

Peraturan Menteri Desa, Pembangunan Daerah Tertinggal, dan Transmigrasi Republik Indonesia Nomor 4 Tahun 2015 tentang Pendirian, Pengurusan dan Pengelolaan, dan Pembubaran Badan Usaha Milik Desa.

Peraturan Pemerintah Republik Indonesia Nomor 72 Tahun 2005 tentang Desa

Pujawan, I. Nyoman (2005). Supply Chain Management. Surabaya: Guna Widya. Ramadana, Coristya Berlian, Heru Ribawanto dan Suwondo. 2013. Keberadaan Badan Usaha Milik Desa (BUMDES) Sebagai Penguatan Ekonomi Desa (Studi di Desa Landungsari, Kecamatan Dau, Kabupaten Malang). Jurnal Administrasi Publik. Vol. 1 No. 6. Hal 1068-1076.

Sartono, R Agus. 2017. Manajemen Keuangan Teori dan Aplikasi. Yogyakarta : BPFE Wijayanti, Anita Wahyu, Mujibur Rahman Khairul Muluk dan Ratih Nurpratiwi. 2012. Perencanaan Anggaran Berbasis Kinerja di Kabupaten Pasuruan. Jurnal Wacana Vol. 15 no, 3. 